ROCZNIKI TEOLOGICZNE

Volume 65, issue 8 - 2018

Englis h vers i o n

DOI: http://dx.doi.org/10.18290/rt.2018.65.8-5en

REV. BOGUSŁAW MIGUT

\title{
THE LITURGICAL PERSPECTIVE OF THEOLOGY
}

A b st r a ct. An important help in finding the right place for the liturgy in theology and the manner of practicing theology is the new document of the Congregation for the Clergy The Gift of the Priestly Vocation. Ratio Fundamentalis Institutionis Sacerdotalis issued on December 16, 2016. This document provides a new order for the subjects taught in seminaries. Sacred Scripture is put in the first place as the soul of theology (Dei Verbum 24). It is followed immediately by the study of the sacred liturgy, which "must be considered a fundamental discipline." This is because Scripture and the liturgy constitute a living theology, meaning that they are the first and primary locus for all of theology. The fact that the liturgy immediately follows Sacred Scripture is also influenced by a new, in-depth understanding of the liturgy found in the Catechism of the Catholic Church and among contemporary theologians (J. Corbon, A.M. Triacca, A. Schmemann, J. Ratzinger) and a deeper connection of the liturgy with Divine Revelation and its transmission. The author of the article recognizes the particular significance of liturgical theology focused on the joint presentation of the three components of the liturgy, which are the salvific mystery of God, the liturgical celebration and the Christian life. Liturgical theology can be done from the perspective of each of these elements of the liturgy (Mysterium-Actio-Vita). Liturgical theology is the most perfect fulfillment of the liturgical perspective of theology.

Keywords: liturgy; theology; Ratio fundamentalis 2016; Bible; theologia prima; theologia secunda; Divine Revelation; the transmission of Divine Revelation; liturgical theology; systematic theology; pastoral theology.

A valuable assistance in finding the right place for the liturgy in theology and the method of doing theology is the new document of the Congregation for the Clergy of the Apostolic See on December 16, 2016, entitled The Gift of the Priestly Vocation. Ratio fundamentalis institutionis sacerdotalis. ${ }^{1}$ This document gives a new order of subjects taught in priestly formation seminaries. Studying Sacred Scripture is placed as the priority, because it is the

Rev. Dr. Hab. BogusŁaw Migut, KUL professor and director of the Institute of Liturgy and Homiletics for the Faculty of Theology at KUL, Chair of Liturgical Theology and Spirituality; correspondence address: Al. Racławickie 14, 20-950 Lublin, Poland; e-mail: bmigut@ kul.lublin.pl

${ }^{1}$ Vatican: L'Osservatore Romano 2016 (further abbreviated RFIS). 
soul of theology (cf. DV 24), ${ }^{2}$ and immediately afterward is the study of the sacred liturgy which "should be considered as the basic discipline." 3 Successive points mentioned by the document include dogmatic theology along with sacramentology, moral theology, pastoral theology, missiology, the Church's social teaching, Church history, canon law and "other disciplines (e.g. ecumenism and the history of religion)."

\section{WHY IS THE LITURGY DIRECTLY AFTER THE BIBLE IN THE NEW RATIO FUNDAMENTALIS?}

The question that comes out concerns the second place of the liturgy directly after the Bible, and before dogmatic theology or moral theology. It is difficult for the Congregation to depreciate dogmatic theology and moral theology towards the discipline which, in popular opinion, deals with the "Catholic rite." The first answer is to refer to the two main loci theologici of Christian theology, which are the Bible and the liturgy. The second answer to the question about appreciating the liturgy when ranking theological disciplines is related to the question about a new, in-depth understanding of the liturgy in relation to a new and in-depth understanding of theology, having its source in a new, deepened understanding of divine revelation.

\subsection{THE MUTUAL RELATIONSHIP BETWEEN THE LITURGY AND THE BIBLE}

Understanding the liturgy in Ratio fundamentalis as the main locus theologicus after Sacred Scripture requires a new analysis of the Council's (Vatican Council II) and the post-Conciliar postulates of Church teaching concerning the liturgy's place in theology and the new liturgical direction of theology. It is worth first of all noting that this document is a reference to the division of theology which was present in some of the Eastern Fathers and in some participants of the liturgical movement. This consists in pointing

\footnotetext{
${ }^{2}$ Cf. RFSI 166.

${ }^{3}$ RFSI 167. The same in the English version reads: "The sacred liturgy must be considered a fundamental discipline," and the Italian version: "La sacra liturgia deve essere considerata una disciplina fondamentale."

${ }^{4}$ RFSI 175.
} 
to two types of theology, which are primary theology (theologia prima) and secondary theology (theologia secunda). Primary theology is the Sacred Scripture and the liturgy, because the Bible is the place where God reveals himself in his words and deeds written down by the inspired authors, and the liturgy is the place of the sacramental manifestation and action of the Word of God in Jesus Christ during the formation of the Church. Louis Bouyer emphasizes this when he states:

Only in the Church, which is the Body of Christ, the living Word of God in Christ does not cease to be present among us, and it does not cease to speak to us at in our times. The Spirit of Christ does not cease to dwell only in the Body of Christ, as the Spirit is always animating. We experience this in a special way during the celebration of the liturgy. This is because the liturgical assembly of the Church is a congregation of the People of God convened by God Himself above all to listen to His Word. ${ }^{5}$

For L. Bouyer, the People of God gathering for the liturgy, meaning the communal listening to the Word of God, is not something artificial, which would happen as if after the fact to restore youth to a document that has grown old. On the contrary, Bouyer states that:

This is the normal way by which they arose, and then the biblical texts were collected; it is the way in which they should always be accepted, just as they were given to us. To be convinced about this, it is enough to consider the decisive moments in the history of the People of God, which are at the same time decisive moments in Biblical history, and as it presents these to us. ${ }^{6}$

Theology connected with the Bible and the liturgy is primary theology, because the salvific event transmitted in the Bible is made sacramentally present in the liturgy. The salvific event and its presence during the time of the Church's formation and the liturgy constitute one whole. Odo Casel was the theologian who initiated this approach in the $20^{\text {th }}$ century. For him, theology is "a view of the mystery of God in the light of the liturgy" (eine im Geist der Liturgie Gesamtschau), in the light of its symbolism in the image it creates. Only from this perspective is it possible to fully grasp the essence of Christianity (Gesamt aussprache über das Wesen des Christentums). ${ }^{7}$

\footnotetext{
${ }^{5}$ Louis BOUYER, Wprowadzenie do życia duchowego. Zarys teologii ascetycznej i mistycznej, transl. Lucyna Rutowska (Warsaw: Instytut Wydawniczy PAX, 1982), 27; Cf. Davide ZordAN, Connaissance et Mystère. L'itinéraire théologique de Louis Bouyer (Paris: Cerf, 2008), 135-138.

${ }^{6}$ BOUYER, Wprowadzenie do życia duchowego, 27.

${ }^{7}$ Cf. Wacław ŚwiERZAwski, Dynamiczna „Pamiątka” Pana. Eucharystyczna anamneza Misterium Paschalnego i jego egzystencjalna dynamika (Kraków: PTT, 1980), 94.
} 
Father Casel emphasizes that the most valuable theology is the one that shows God's reality through the prism of the celebrated mystery, meaning through the prism of its symbolism. Only such a theology "opens up the vast and fascinating dimension of the reality of salvation, reveals its Christocentrism, brings out the personal character of sacramental mediation and thereby brings fertile inspiration" for other ways of practicing theology, but also for Christian spirituality. ${ }^{8}$

This was also Salvatore Marsili's opinion, one of the representatives of the Roman school, according to whom recognizing the liturgy within the primary theology is mainly based on genetic-historical reasons. He refers mainly to John Kasjan (circa 360-435), Evagrius Ponticus (345-399) and Diodochus from Photika (about 400-485). They perceived the liturgy as the first theology (teologia prima), because they perceived it as the original reality in which the confession of faith, transformed into a faith experience, becomes the first concrete, though symbolic, way of expressing theological thought. In fact, the liturgy in the historical order came before any dogma and any other way of expressing faith (fides quae). The only thing that precedes the liturgy and its inherent prominence is the act of faith (fides qua). S. Marsili states that the liturgical way of theologically "speaking" in the Church is the basis of all other reflections aimed at explaining what in symbolic language was manifested in the liturgy (theologia secunda). ${ }^{9}$

From the very beginning, the liturgy was and is a comprehensive expression of faith, though it required further reflection and clarification. The liturgical tradition is the first and most common test of orthodoxy, but it is also theology to the highest degree prayed and lived out. All theological reflection was born from the liturgy, even reflections over the liturgy itself. For living theology, the whole internal experience counts, not just purely intellectual cognition. This presupposes a new understanding of theology, but also of the liturgy, as will be discussed later in the article. ${ }^{10}$ Pointing to the importance of primary theology (theologia prima) is not rejecting or diminishing the importance of secondary theology (theologia secunda). Primary theology postulates the existence of theologia secunda, whose task is first of all to carry out further and constantly renew research on the way in

\footnotetext{
${ }^{8}$ Cf. IBIDEM, Pro cuius amore. Myślenie, modlitwa i czyn (Wrocław: WWKA, 1984), 258.

${ }^{9}$ Cf. Salvatore MARsili, "Teologia liturgica," in Nuovo dizionario di liturgia, ed. Domenico Sartore, Achille M. Triacca (Roma: San Paolo Edizioni, 1984²), 1513.

${ }^{10}$ Cf. Bogusław Migut, Teologia liturgiczna szkoły rzymskiej (Lublin: Wydawnictwo KUL, 2007), 116
} 
which the mystery of Christ is actualized in the world, and second, it is to seek forms of expressing in the language of modern culture what is expressed in the liturgy in a symbolic language. ${ }^{11}$

\subsection{A NEW UNDERSTANDING OF THE LITURGY AND DIVINE REVELATION}

The basis for such an appreciation of the liturgy in theology is the relationship between the Bible and the liturgy described above, but also a new and in-depth understanding of the liturgy itself and a deeper understanding of divine revelation, assuming its ties to the liturgy. The most important step in discovering the essence of the liturgy was the extraction and presentation of its Christocentrism by Pope Pius XII. It is worth noting that this took place at a time when the Church was rediscovering its nature as the Mystical Body of Christ. Highlighting Christocentrism in the liturgy makes the Church realize once again that it lives thanks to the liturgy, that the Church draws from this liturgy, but also that man himself is not able to worship God. The only one who can worship God and fulfill worship is the one who became a man, meaning God's Son who, as the Head, honors the Father by including the members of his Mystical Body. Further development of the understanding of the liturgy takes place in the Constitution on the Liturgy of Vatican Council II (CL 7), where Christocentrism additionally acquires a historical character.

The liturgy embraces the entire history of salvation, stemming from the heart of the Triune God, finds its origin in the created world in the heart of the God-Man and is fulfilled in the heavenly liturgy in eschatological worship (CL 5-8). Already in the Council's teaching, it is clear that the liturgy cannot be limited to rituals, that is, the celebration itself, although each liturgical celebration is a synthesis of the entire history of salvation and the fullest participation in the life of God on earth. The next important point in understanding the liturgy is the Catechism of the Catholic Church, which, recalling the conciliar definition, expands it to include the inner-Trinitarian and cosmic aspects. According to the Catechism, the liturgy reflects the pattern of

\footnotetext{
${ }^{11}$ Cf. Salvatore MARsili, La liturgia nel discorso teologico odierno. Per una fondazione della liturgia pastorale: Individuazione delle prospettive e degli ambiti specifici, in: Una liturgia per l'uomo. La liturgia pastorale e i suoi compiti, ed. Pelagio Visentin, Aldo Natale Terrin, Romano Cecolin (Padova: EMP, 1986), 43.
} 
the blessed relationship between God and man. God grants his blessing in the work of creation and salvation, and the blessing is the gift and Word of God. From the human side, it is adoration and offering oneself in thanksgiving for the received gifts. From the beginning of time, starting with the liturgical poem about the creation of the world in the book of Genesis, the entire work of God is a blessing given by God. Its source is the inner life of the Holy Trinity.

According to the Catechism, the liturgy begins in love, in the mutual penetration and sharing of the Divine Persons (perichoresis). Only the second stage of the liturgy is God giving outside himself, first in the creation of the world, and then its salvation and redemption in Jesus Christ. All of God's blessings and the whole history of salvation are a liturgy. In the chain of God's blessings, on the part of man, the liturgy is thanksgiving in Jesus Christ through the power of the Holy Spirit. The height of liturgy understood in this way is Jesus Christ himself, who is the greatest blessing from God, meaning a gift given to man, and at the same time in Jesus Christ, the blessing is able to return to the Father as man's adoration, and on the part of all creatures through man.

This very broad understanding of the liturgy comes from Eastern theology, specifically from the Lebanese theologian Jean Corbon of French origin (1924-2001) who was asked by Cardinal Ratzinger to work on the Catechism of the Catholic Church. His greatest influence can be seen in the second part of the Catechism, which is entitled The Celebration of the Christian Mystery, in the first chapter devoted to the liturgy and sacramental economy. ${ }^{12}$ Corbon's main book on the liturgy, entitled The Wellspring of Worship, presents it as a Mystery having its source in the inner-Trinitarian life of God, but also in the fullness of the mystery which is Jesus Christ. The liturgy is also a celebration and permeates the entire Christian life. The mystery of the liturgy according to Corbon is a river of life and love flowing from the throne of God. This river was closed by original sin, but in the mystery of Jesus Christ, especially in his paschal mystery, the river was reopened.

The liturgy is performed by Christ sitting at the right hand of the Father. From the Descent of the Holy Spirit at Pentecost, the mystery of the liturgy

${ }^{12}$ Cf. Tomasz KwIECIEŃ, "Wprowadzenie," in Jean CoRBon, Liturgia-źródto wody życia, transl. Anna Foltańska (Poznań: W drodze, 2005), 5; Krzysztof PorosŁo, "Wpływ teologii liturgii Jeana Corbona na sekcję liturgiczną «Katechizmu Kościoła Katolickiego»," Roczniki Teologiczne 61 (2014), folder 8: 137-139. 
embraces the Church and becomes a celebration accomplished by Christ and through the Church.

On $[\ldots]$ the morning of Pentecost, the Holy Spirit performs in a virgin way the conception of the Body of Christ, woven from our humanity, meaning the Church. The Spirit who comes from the Father is given by the Lamb that was slain, and the eternal liturgy surges into our world. This is how a new creature appears, Christ's body is not only present among people, but it begins to 'unite' all human beings. ${ }^{13}$

J. Corbon defines the celebration of the liturgy as the "epiphany of the liturgy" in the times of the Church, "because the liturgy pours out into a celebration. A great sacrament, which is the Body of Christ, will be able to embrace us. Next, we will see the unstoppable expansion of the Lord's ascension, the transformation of every human life, time and space in the sacraments." 14 The third element of the liturgy is its penetrating the Christian life.

The liturgy, which is the mystery of the river of life flowing from the Father and the Lamb, touches and draws us. We celebrate it so that it will fertilize and enrich our entire life. The eternal liturgy, in which the economy of our salvation finally takes hold, is 'fulfilled' by us, in our sacramental celebrations, in order that we may find ourselves in our smallest fibers and our human community. ${ }^{15}$

A similar, though not identical, approach to the liturgy was presented by Achille Maria Triacca SDB (1935-2002), whose liturgical theology strongly emphasized the coexistence of the three elements forming the liturgy. Just like J. Corbon, he distinguishes the salvific mystery of God that comes from within the Holy Trinity, finds its fullness in Jesus Christ and embraces salvation history (Mysterium). The mystery of the liturgy is actualized and fulfilled in every particular liturgical celebration (Actio), so that it can embrace the whole of Christian life and lead to its becoming a liturgy (liturgy of life-Vita). From the human side, the liturgy is a life which, in order to become adoration for God, and thus be embraced by his saving mystery, must be included in the liturgical celebration. ${ }^{16}$

\footnotetext{
${ }^{13}$ CoRbon, Liturgia-źródto wody życia, 70.

${ }^{14}$ Ibidem, 110.

${ }^{15}$ Ibidem, 189.

${ }^{16}$ Cf. Achille M. TRIACCA, "Sacerdozioministeriale: valenzeteologico-trinitarie. Contributo alla Spiritualità del presbitero," Liturgia 32 (1998): 413; IBIDEM, "'Liturgia' 'locus theologicus' o 'theologia' 'locus liturgicus'? Da un dilemma verso unasintesi," in: Paschale Mysterium. Studi in memoriadell'Abate Prof. Salvatore Marsili (1919-1983), ed. Giustino Farnedi, (series: Studia Anselmiana 91. Analecta Liturgica 10) (Roma: Benedictina-Ed. Abbazia S. Paolo, 1986), 193-233.
} 
Similarly, a broad understanding of the liturgy is represented by the modern Orthodox theologian Alexander Schmemann (1921-1983). He starts with

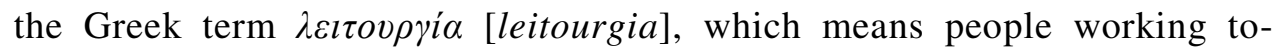
gether and the fulfillment of their vocation, realizing their mission, and thus becoming God's tool in the world in fulfilling His will. "Liturgy" to him

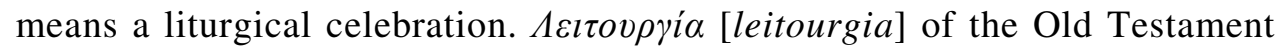

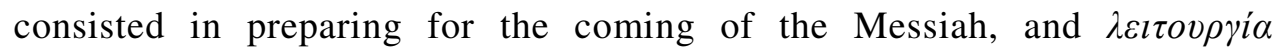
[leitourgia] in Jesus Christ means his entire life and the perfect fulfillment

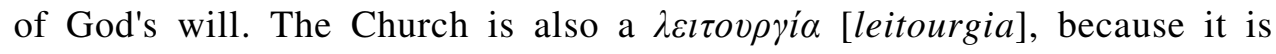
called to follow the model of Christ and to build the Kingdom of God together with him and the power of the Holy Spirit. ${ }^{17}$ Commenting on A. Schmemann, in the language of J. Corbon and A.M. Triacca, it can be stated that $\lambda$ citovpyí [leitourgia] embraces the salvific mystery of God and the Christian life, although it is particularly strongly connected with the latter. The liturgy is the sacramental presence of the saving mystery of

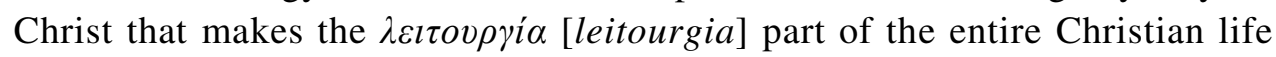
in all its dimensions.

The high position of the liturgy in the new Ratio fundamentalis also stems from the close connection of the liturgy with divine revelation and its participation in its transmission. The Constitution on Divine Revelation Dei Verbum broadens our understanding of revelation in comparison with the teachings of previous councils, especially Vatican I. The Constitution on Divine Revelation of Vatican Council II states:

In His goodness and wisdom God chose to reveal Himself and to make known to us the hidden purpose of His will (see Eph. 1:9) by which through Christ, the Word made flesh, man might in the Holy Spirit have access to the Father and come to share in the divine nature [...] Therefore, the invisible God [...] out of the abundance of His love speaks to men as friends [...] and lives among them [...], so that He may invite and take them into fellowship with Himself (DV 2).

Revelation is not limited to the doctrinal contents itself, because it is primarily God sharing himself. It is the whole of God's deeds and words in salvation history. The saving acts are the first Word of God, and their interpretation is the second word, the comments. God's active revelation, not the revealed truths themselves, is therefore the contents of the Bible's salvation

\footnotetext{
${ }^{17}$ Cf. Alexander Schmemann, Za życie świata, transl. Andrzej Kempfi (Warsaw: Novum, 1998), 20; David FAgerberg, Theologia prima. Czym jest teologia liturgiczna?, transl. Laura Bigaj (Kraków: Fundacja Dominikański Ośrodek Liturgiczny, 2018), 38-47.
} 
history. Thus, revelation as God sharing himself has a historical and interpersonal dimension, or personalistic. ${ }^{18}$ This understanding of revelation, in the teachings of the Council, allows us to speak in a proper way about God's saving work for people. Based on this, we can speak about God's dual activity. The first is action through historical revelation throughout salvation history in the Old and New Testaments, primarily in Jesus Christ. The second is a supra-historical activity, namely sacramental, though at the same time it is historical. The subject of this activity is Jesus Christ, in whom deed and word become one. He is the Word of God through His ontology, deeds and preaching. ${ }^{19}$

With such a grasp of divine revelation as God sharing himself for the life of the world, we can easily see an analogy to the new understanding of the liturgy which is presented in the Catechism of the Catholic Church and in the theology of J. Corbon, A.M. Triacca, but also in A. Schmemann. In the salvation history and personalistic structure of revelation, it is easy to find a similarity to the three main components of liturgy as a blessing, meaning a salvific mystery in which God reveals himself through sharing, a celebration in which this saving mystery is actualized, and, therefore, is shared with people throughout their lives to transform the world and build the Kingdom of God.

Another issue is the message of revelation, in which the liturgical celebration, commonly known as the liturgy, plays an important role. Marian Rusecki makes the starting point of his reflection the statement that "the Church is realized in the liturgy and through it," and thus from the very beginning of its life, the Church fulfills an important and irreplaceable function in the process of the message of revelation. He also points to the historical primacy of lex orandi vs. lex credendi by stating: "a long time was needed to form the Church's dogmas, before theology developed, whereas what is essential for the faith and life of the Church was present in the liturgy from the beginning." ${ }^{20}$ However, the liturgical celebration is not only the place for the transmission of revelation, but in it, revelation continues as God sharing himself, it is constantly being done.

\footnotetext{
${ }^{18}$ Cf. Marian Rusecki, Traktat o Objawieniu (Kraków: Wydawnictwo Księży Sercanów, 2007), 95-98, 105-112.

${ }^{19}$ Cf. Bogusław Migut, "Teologia liturgiczna jako ukierunkowanie teologii na Objawienie Boże w perspektywie życia chrześcijańskiego," in Félix María ArocenA, David W. FAGERberG, Bogusław Migut, Manlio Sod, Teologia liturgiczna. W poszukiwaniu syntezy teologii, ed. Bogusław Migut (Lublin: Wydawnictwo KUL, 2013), 143-144.

${ }^{20}$ RUSECKI, Traktat o Objawieniu, 505.
} 
The basic source for theology, the place where theology is brought to life, and not just through arguments, is Divine Revelation itself, meaning Sacred Scripture and Tradition. The appearance of Tradition is a result of a Scriptural life, the Word of God in the Church, which is defined by the Conciliar Constitution Dei Verbum as creatura Verbi and sponsa Verbi (DV 23). There are three determinants of the credibility of the Church's Tradition, which are the Church's faith and the two main ways it exists. According to Hermann J. Pottmeyer, the determinants of Tradition are: compliance in the diachronic dimension, the duration of a given case (antiquitas), compliance in the synchronous dimension, referring to the past and present (universitas) and a formal type of conformity, that is, acknowledging something as truth through the Teaching Office of the Church (formalitas). ${ }^{21}$ Handing down the message of Tradition is carried out in three ways: by preaching (lex credendi), liturgical celebration (lex orandi) and the life of the Church community (lex vivendi).

This fact is clearly emphasized by the Constitution on Divine Revelation in the words: "the Church, in her teaching, life and worship, perpetuates and hands on to all generations all that she herself is, all that she believes" (DV 8). The privileged place of the life of Tradition in the Church is held by the Fathers of the Church and the liturgy, which is why the Council recommends "the study of the holy Fathers of both East and West and of sacred liturgies" (VD 23). The above statements constitute the foundation for practicing theology, which should focus on Scripture and Tradition and on the three main ways of their transmission, namely the teaching the Church, the life of the Church and its liturgy. ${ }^{22}$ These statements are guidelines for theology, where it should seek the truth and which ought to be the center of its attention. ${ }^{23}$

\section{THE PLACE OF THE LITURGY IN THEOLOGY}

In addition to the liturgy being ranked directly after the Bible, the new Ratio fundamentalis says nothing directly about the place of the liturgy in

${ }^{21}$ Cf. Hermann J. PotTMEYeR, Normen, Kriterien und Strukturen der Überlieferung, in: Handbuch Der Fundamentaltheologie, ed. Hermann Pottmeyer, Max Seckler, Kern Walter, vol. IV (Stuttgart: UTB, 2000), 101.

${ }^{22}$ Cf. Lubomir ŽÁK, "La teologia: statuto, metodo, fonti, strumenti," in Teologia fondamentale, vol. I, Epistemologia generale, ed. Giuseppe Lorizio (Roma: Città Nuova, 2004), 133-138.

${ }^{23}$ Cf. Bogusław Migut, "Teologia liturgiczna. Teologiczna nauka o liturgii w niemieckim obszarze językowym. Geneza i założenia teoretyczne,” Teologiczne Studia Siedleckie 12 (2015): 255-256. 
theology. Therefore, in this respect, it is worth referring to the documents of the Second Vatican Council, mainly to the Constitution on the Sacred Liturgy Sacrosanctum Concilium (SC 16) and the Decree on Priestly Training Optatam Totius (OT 16). First, however, we ought to draw attention to the way of practicing the theological discipline dealing with the liturgy.

\subsection{HOW TO UNDERTAKE THEOLOGICAL STUDIES ON THE LITURGY}

The Ratio devotes a lot of space to undertaking liturgical studies, pointing to its theological and systematic character and explicitly separating it from pastoral theology referred to in point 170 . The practical and formative dimensions of the liturgical celebration are presented in a separate point, without including this contents into the main theological interpretation of the liturgy. In point 177 , the Ratio states: "It is particularly advisable to study ars celebrandi, to teach priesthood candidates how to fruitfully participate in the holy mysteries and practically celebrate the liturgy with respect and faithfulness to the liturgical books." Going back to point 167 , it is worth noting that neither here nor in DV 16 or in DPT 16 appears the name "liturgics" in reference to the theological study of the liturgy.

Here we are speaking about the "sacred liturgy" as a discipline: DV 16 speaks of "the teaching on the sacred liturgy" (disciplina de sacra Liturgia), and DPT 16 about the "sacred liturgy" (sacra Liturgia). It is worth paying attention to this, because the name "liturgics" was abandoned in many languages, and this was caused by the overly technical and practical treatment of the liturgy in the title. As early as 1921, Romano Guardini directly avoided the term "liturgics" because, in his opinion, it clearly shows that the theological teaching about the liturgy belongs to pastoral theology. ${ }^{24}$ The appearance of RFIS in 2016 is a good opportunity to discuss the adequate name of this theological discipline about the liturgy.

According to RFIS 167, the pastoral aspect is one of the four aspects in practicing theological studies on the liturgy, in addition to theology, spirituality and law. The Constitution on the Liturgy no. 16 lists five aspects when teaching about the liturgy: theological, historical, spiritual, pastoral

\footnotetext{
${ }^{24}$ Cf. Romano GAURDINI, "Über die systematische Methode in der Liturgiewissenschaft," Jahrbuch für Liturgie wissenschaft 1 (1921): 108.
} 
and legal. The historical aspect only seems to disappear in RFIS, because in the further part of the text it states that "seminarians should grasp the essential and unchangeable nucleus of the liturgy, as well as that which belongs instead to particular historical settings" (RFIS 167). The historical aspect is thus even stronger and closer to the theological.

"Additionally, by exploring the texts and rites both of the East and of the West, the sacred liturgy must be seen as an expression of the faith and of the spiritual life of the Church" (RFIS 167). This statement apparently presents the essence of the theological study of the liturgy, consisting of the discovery and presentation of the lex orandi of the Church in relation to the lex credendi. This refers to the teachings of the above-mentioned R. Guardini: "The subject of the systematic study of the liturgy is therefore a living Church, offering, praying and performing the mysteries of grace, that is, a Church that actually performs worship with all its signs." 25

\subsection{WHY THE LITURGICAL PERSPECTIVE IN THEOLOGY?}

The statement in RFIS that all these aspects of the study of the liturgy should be presented "in connection with other disciplines, so that the seminarians can know how the mysteries of salvation are present and operative in the liturgical actions" (RFIS 167). Therefore, responsibility for linking the liturgy with other disciplines lies on the lecturers on the sacred liturgy, whereas in DV 16, this responsibility rested more on the lecturers of other theological disciplines. The study of the liturgy, according to DV 16, is separate from dogmatic theology, Sacred Scripture, the theology of inner life and pastoral theology. Thus, lecturers of these subjects should "according to the internal requirements of their own subjects take into account the mystery of Christ and the history of salvation, so that the relationship of these subjects with the liturgy and its unity with priestly formation be clearly manifested." It seems obvious that for the good of theology, the concern for linking the truths of the faith and Christian life with the liturgy rests on the lecturers who deal with the liturgy, but also on other theological disciplines.

Wishing to point to the necessity of the liturgical perspective for theology, we will briefly refer to everything that has already been said in this article. This perspective is important first of all because Sacred Scripture, as

\footnotetext{
${ }^{25}$ Ibidem, 214.
} 
the main source of divine revelation, through the sacramental work of Christ, live in the liturgy of the Church with the power of the Holy Spirit. The liturgy helps us to "grow in the Church, the true Body of Christ, to participate in the Spirit of Christ and receive His words, not as a dead letter, but as constantly living and life-giving words. These words are always alive in the Church, because they are always expressed in the personal Word of God." 26 The liturgy is the first theology (theologia prima), in which the confession of faith is transformed into the experience of faith and becomes the first concrete, though symbolic, way of expressing theological thoughts, and this is done through prayers and praising God. The liturgy is the place where a theologian's faith, necessary for practicing theology and its study, is built and developed.

John Paul II stated:

If theology (the God-word) is a word about God, the study of God, it is simultaneously a word and study born of the Word of God Himself. This can never be forgotten, and results from particular aspects of the 'study of theology'. For research studies and for every kind of science, the relationship to reality in the truth remains fundamental. All human (scientific) truth of theology confronts the priority of Divine Truth. [...] This is the correct understanding in faith of this Reality, which only as the ultimate fruit of faith can achieve its ultimate reality, that is, the fullness of seeing (making us happy). ${ }^{27}$

Many contemporary theologians realize that the synthesis of theology, whose need is indicated by the Second Vatican Council (DV 16, DPT 16), cannot be solely intellectual, but life-oriented. Theology cannot speak about laws excluded from real-life, but about the reality of a living God revealing himself to people for their lives. That is why theology should concentrate on the mystery of Christ and lead to its vivid perception in the Church, during the liturgical celebration and in the specificity of the Christian life. ${ }^{28}$ This reveals the special significance of liturgical theology, focused on the joint presentation of the three component elements of the liturgy, which are the salvific mystery of God, the liturgical celebration and the Christian life. It can be performed from the perspective of each of the elements of the liturgy.

\footnotetext{
${ }^{26}$ BOUYER, Wprowadzenie do życia duchowego, 17.

${ }^{27}$ JAN PAWEe II, "Przemówienie skierowane na spotkaniu w Częstochowie do uczestników Kongresu Teologicznego Europy Środkowo-Wschodniej w 1991 r.," in Świadectwo Kościoła katolickiego $w$ systemie totalitarnym Europy środkowo-wschodniej. Księga Kongresu Teologicznego Europy środkowo-wschodniej (KUL, 11-15 sierpnia 1991) (Lublin: RW KUL, 1991), 307.

${ }^{28}$ Cf. Migut, Teologia liturgiczna szkoty rzysmkiej, 211.
} 
Liturgical theology is the most perfect fulfillment of the liturgical perspective of theology.

\section{SUMMARY}

A new document from the Congregation for the Clergy of the Holy See from December 16, 2016, entitled The Gift of a Vocation to the Priesthood. Ratio fundamentalis institutionis sacerdotalis, is an important means of finding the proper place of the liturgy in theology and the way to practice theology. It gives us, we can say, the ranking of subjects taught in priestly formation seminaries. First place is given to the study of Sacred Scripture, which are the soul of theology (cf. DV 24), and immediately afterward comes the study of the sacred liturgy, which "should be considered as the basic discipline." This is because the Bible together with the liturgy are a living theology, the primary theology (theologia prima) and the basic locus for all of theology. It is also influenced by a new, in-depth understanding of the liturgy in the Catechism of the Catholic Church and among contemporary theologians such as John Corbon, Achille M. Triacca, Alexander Schmemann and Joseph Ratzinger, with a deeper link between the liturgy and the message of divine revelation. The author recognizes the special significance of liturgical theology, focused on the joint presentation of the three component elements of the liturgy, meaning the salvific mystery of God, the liturgical celebration and the Christian life. It can be exercised from the perspectives of each of the elements of the liturgy. Liturgical theology is the most perfect fulfillment of the liturgical perspective of theology.

\section{BIBLIOGRAPHY}

BOUYER, Louis. Wprowadzenie do życia duchowego. Zarys teologii ascetycznej i mistycznej [Introduction to Spiritual Life. An Outline of Ascetic and Mystical Theology]. Translated by Lucyna Rutowska. Warsaw: Instytut Wydawniczy PAX, 1982.

Corbon, Jean. Liturgia-źródto wody życia [The Wellspring of Worship]. Translated by Anna Foltańska. Poznań: W drodze, 2005.

FAGERBERG, David W. Theologia prima. Czym jest teologia liturgiczna? [Theologia prima. What Is Liturgical Theology?]. Translated by Laura Bigaj. Kraków: Fundacja Dominikański Ośrodek Liturgiczny, 2018.

GAURDINI, Romano. "Über die systematische Methode in der Liturgiewissenschaft." Jahrbuch für Liturgie wissenschaft 1 (1921): 97-108. 
KwIECIEŃ, Tomasz. "Wprowadzenie" [Introduction]. In Jean CORBON. Liturgia-źródto wody życia [The Wellspring of Worship]. Translated by Anna Foltańska, 5-9. Poznań: W drodze, 2005.

MARSILI, Salvatore. “Teologia liturgica.” In Nuovodizionario di liturgia, ed. Domenico Sartore, Achille M. Triacca, 1508-1525. Roma: San Paolo Edizioni, 1984².

MARSILI, Salvatore. "La liturgia nel discorso teologico odierno. Per una fondazione della liturgia pastorale: Individuazione delle prospettive e degli ambiti specifici." In Una liturgia per l'uomo. La liturgia pastorale e i suoi compiti, ed. Pelagio Visentin, Aldo Natale Terrin, Romano Cecolin, (series: Caro Salutis Cardo), 14-47. Padova: EMP, 1986.

Migut, Bogusław. Teologia liturgiczna szkoty rzymskiej [Liturgical Theology in the Roman School]. Lublin: Wydawnictwo KUL, 2007.

Migut, Bogusław. "Teologia liturgiczna jako ukierunkowanie teologii na Objawienie Boże w perspektywie życia chrześcijańskiego" [Liturgical Theology as the Orientation of Theology to Divine Revelation in the Perception of Christian Life]. In Félix María Arocena, David W. FAgERBerg, Bogusław Migut, Manlio Sodi. Teologia liturgiczna. W poszukiwaniu syntezy teologii, 139-183 [Liturgical Theology. In Search of a Synthesis in Theology], edited by Bogusław Migut. Lublin: Wydawnictwo KUL, 2013.

Migut, Bogusław. "Teologia liturgiczna. Teologiczna nauka o liturgii w niemieckim obszarze językowym. Geneza i założenia teoretyczne" [Liturgical Theology. Theological Teaching about the Liturgy in the German Language. Genesis and Theoretical Assumptions]. Teologiczne Studia Siedleckie 12 (2015): 253-266.

PorosŁo, Krzysztof. "Wpływ teologii liturgii Jeana Corbona na sekcję liturgiczną «Katechizmu Kościoła Katolickiego»" [The Influence of the Liturgy of Jean Corbon on the Liturgical Section of the "Catechism of the Catholic Church"]. Roczniki Teologiczne 61 (2014), folder 8: 133-152.

POTTMEYER, Hermann J. "Normen, Kriterien und Strukturen der Überlieferung." In Handbuch Der Fundamentaltheologie, edited by Hermann Pottmeyer, Max Seckler, Kern Walter, vol. IV, 124152. Stuttgart: UTB, 2000.

RUSECKI, Marian. Traktat o Objawieniu [Treatise on Revelation]. Kraków: Wydawnictwo Księży Sercanów, 2007.

Schmemann, Alexander. Za życie świata [For the Life of the World]. Translated by Andrzej Kempfi. Warsaw: Novum, 1998.

ŚwIERZAwsKi, Wacław. Dynamiczna „Pamiątka” Pana. Eucharystyczna anamneza Misterium Paschalnego i jego egzystencjalna dynamika [The Lord's Dynamic "Remembrance." The Eucharistic Anamnesis of the Paschal Mystery and its Existential Dynamics]. Kraków: PTT, 1980.

ŚwierZawski, Wacław. Pro cuius amore. Myślenie, modlitwa i czyn [Pro cuius amore. Thoughts, Prayer and Action]. Wrocław: WWKA, 1984.

TRIACCA, Achille M. “'Liturgia' 'locus theologicus' o 'theologia' 'locus liturgicus'? Da un dilemma verso unasintesi." In Paschale Mysterium. Studi in memoria dell'Abate Prof. Salvatore Marsili (1919-1983), ed. Giustino Farnedi, (series: Studia Anselmiana 91. Analecta Liturgica 10), 193-233. Roma: Benedictina-Ed. Abbazia S. Paolo, 1986.

TriacCA, Achille M. "Sacerdozio ministeriale: valenze teologico-trinitarie. Contributo alla Spiritualità del presbitero." Liturgia 32 (1998): 413.

Zordan, Davide. Connaissance et Mystère. L'itinéraire théologique de Louis Bouyer. Paris: Cerf, 2008. 
ŽÁK, Lubomir. "La teologia: statuto, metodo, fonti, strumenti." In Teologia fondamentale, vol. I, Epistemologia generale, edited by Giuseppe Lorizio, 11-233. Roma: Città Nuova 2004.

Translated by Jan Kobytecki

The preparation of the English version of Roczniki Teologiczne (Annals of Theology) and its publication in electronic databases was financed under contract no. 836/P-DUN/2018 from the resources of the Minister of Science and Higher Education for the popularization of science. 